\title{
Effect of starter form, starch concentration, and amount of forage fed on Holstein calf growth from 2 to 4 months of age
}

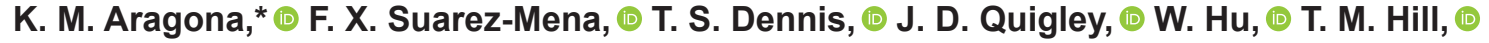 \\ and R. L. Schlotterbeck (i) \\ Nurture Research Center, Provimi, Cargill Animal Nutrition, Brookville, OH 45309
}

\section{ABSTRACT}

Young, weaned calves are commonly offered ad libitum forage with limited amounts of starter, in contrast to the suggested amount of approximately $5 \%$ forage in the diet due to the limited capacity of the rumen, as well as limited ability to digest high fiber feeds. The objective of this research was to compare 2 types of starters (low starch, pelleted vs. high starch, textured), both fed either ad libitum with $5 \%$ chopped hay, or fed at restricted rates with ad libitum long grass hay to calves between 2 and 4 mo of age. In trial 1, 48 calves were housed in group pens $(68.4 \pm 3.37 \mathrm{~kg}$ of initial body weight \pm standard deviation; 3 pens of 4 calves/ pen) and randomly assigned to 1 of 4 diets: (1) low starch pelleted starter (8\% starch) blended with $5 \%$ chopped hay fed free choice; (2) high starch textured starter (45\% starch) blended with 5\% chopped hay fed free choice; (3) low starch pelleted starter (8\% starch) fed at a rate up to $2.3 \mathrm{~kg}$ of dry matter $(\mathrm{DM}) / \mathrm{d}$, with free-choice long grass hay; or (4) high starch textured starter ( $45 \%$ starch) fed at a rate up to $2.3 \mathrm{~kg}$ of DM/d, with free-choice long grass hay. Trial 1 was analyzed as a completely randomized design using a $2 \times 2$ arrangement of treatments. Repeated measures were used as appropriate. Pen was the experimental unit. In trial 2, 48 calves $(76.4 \pm 1.55 \mathrm{~kg}$ of initial body weight; 6 pens of 4 calves/pen) were randomly assigned to 1 of 2 diets: (1) ad libitum access to a blend of 95\% high starch textured starter (42\% starch) and 5\% chopped grass hay; or (2) high starch textured starter fed up to $2.7 \mathrm{~kg}$ of $\mathrm{DM} / \mathrm{d}$ with free-choice long grass hay. Trial 2 was analyzed as for trial 1, without factorial arrangement. Trials were $56 \mathrm{~d}$ long. In trial 1, feed efficiency, average daily gain (ADG), and change in hip width were greater for calves fed high versus low starch diet. Final hip width, ADG, DM intake, and change in hip width

Received August 20, 2019.

Accepted November 14, 2019.

*Corresponding author: karagona@provimi-na.com were greater for calves fed limited chopped versus freechoice long hay diets. In trial 2, intake, feed efficiency, and all growth measurements were greater in calves fed the ad libitum mixed diet compared with those limitfed starter up to $2.7 \mathrm{~kg}$ as fed with ad libitum hay. Ad libitum hay intake was highly variable among pens and differed up to 2.5 -fold by the last week of the trials. In both trials, restricted feeding of starter with ad libitum long grass hay reduced total DM intake by 13 to $17 \%$, ADG by $20 \%$, and hip width change by 10 to $23 \%$ compared with a blend of $95 \%$ starter and $5 \%$ chopped grass hay fed ad libitum.

Key words: dairy calf, forage, growth, efficiency

\section{INTRODUCTION}

Feeding programs for young calves during the first 4 mo of life vary markedly in the United States. For example, the 2014 National Animal Health Monitoring System survey (USDA, 2018) reported that preweaned heifer calves on very small farms $(<30$ cows) were offered starter and forage beginning at 17.6 and $29.9 \mathrm{~d}$ of age, respectively, whereas large operations ( $>500$ cows) began offering starter and forage at 6.3 and 58.1 d of age, respectively. Also, starters fed to calves from birth through approximately 4 mo of age vary in form and formulation. Pelleted, textured, and meal forms are widely used. Content of carbohydrates may also vary. Formulations may range in starch from approximately 10 to $50 \%$. Although research is limited, mostly from one laboratory, high starch diets have been shown to support more growth than low starch diets in calves greater than 8 wk of age (Hill et al., 2008, 2012, 2016), primarily due to greater digestibility of starch compared with fiber (Hill et al., 2016). Intake and growth of calves from 2 to $4 \mathrm{mo}$ of age were not different when offered textured or pelleted high starch starters (Hill et al., 2012), yet there is concern that feeding pelleted starters with high starch concentrations leads to rumen acidosis (Kertz, 2007). Research by Hill et al. (2008, 2012,2016 ) was conducted by feeding a blend of $95 \%$ starter and $5 \%$ forage, offered for ad libitum consump- 
tion from 2 to 4 mo of age, and not with the starter portion restricted, as is common on some farms.

Calf starter forms greatly vary and range from a meal, to a complete pellet, to a textured feed (Bateman et al., 2009; Pazoki et al., 2017). Textured starter feeds can contain steam-flaked, highly processed grains, or whole grains, with varying proportions of grain and pellet. Grains can differ in their fermentation characteristics and be slowly fermented, such as corn and oats, or more rapidly fermented such as wheat and barley. Differences in grain sources have been shown to influence calf starter digestion and calf growth (Khan et al., 2008), as have methods of processing (Porter et al., 2007; Mirghaffari et al., 2013; Suarez-Mena et al., 2015). In commercial settings in the United States, textured feeds tend to have a greater concentration of grain and starch compared with completely pelleted feeds.

Starter can be fed alone, blended with forages, or fed with free-choice forage. Increasing the level of forage that is blended with starter reduced the growth of calves (Hill et al., 2010, 2012), and approximately $1.5 \%$ NDF from forage has optimized growth from 8 to 16 wk of age (Hill et al., 2010). Others (Moeini et al., 2017; Pazoki et al., 2017) have reported that addition of $10 \%$ forage to ground starter increased DMI and BW gain to $70 \mathrm{~d}$ of age and improved intestinal morphology compared with pelleted or ground starters without forage. A meta-analysis (Imani et al., 2017) found that ADG was greater when calves were fed $>10 \%$ forage compared with $<10 \%$ forage. However, the addition of forage to pelleted or ground starters did not affect ADG, but addition of forage to textured starter decreased ADG. Differences in forage type have also led to varying results. Empty BW was greater for calves fed a pelleted starter supplemented ad libitum oat hay but was decreased with ad libitum alfalfa hay (Castells et al., 2013). However, the authors found that actual intake of oat hay was $4 \%$ of total solid feed intake, whereas intake of alfalfa hay was $14 \%$ of solid feed intake. More information is needed for the use of forages, especially when fed ad libitum and starter intake is restricted. Much of the previous research discussed above occurred in calves less than 10 wk of age, and more information is needed in calves 2 to 4 mo of age. This information would be particularly useful in modeling growth and understanding changes in intake with age during the critical transition a calf makes to consuming a high forage diet.

The objective of this research was to compare 2 common forms of starters fed in the United States (low starch, pelleted vs. high starch, textured), both fed either ad libitum with $5 \%$ chopped hay, or fed at restricted rates with ad libitum long grass hay to calves between 2 and 4 mo of age. We hypothesized that restricting concentrate intake and feeding ad libitum hay would reduce DMI and growth compared with feeding 95\% concentrate diets blended with $5 \%$ hay, and that high starch starters would support more growth than low starch starters, regardless of feeding method.

\section{MATERIALS AND METHODS}

All animals were cared for as described in the Guide for the Care and Use of Agricultural Animals in Research and Teaching (FASS, 2010). Holstein steers (58 to $59 \mathrm{~d}$ of age) were housed at the Nurture Research Center in southwest Ohio in pens that had $6.5 \mathrm{~m}^{2}$ of outside pen space and $1.35 \mathrm{~m}^{2}$ of inside pen space per calf. The inside pen space was bedded with long wheat straw and no heat was added.

In trial 1,48 calves $(68.4 \pm 3.37 \mathrm{~kg}$ of initial BW; 3 pens of 4 calves/pen) were randomly assigned to 1 of 4 diets: (1) low starch pelleted starter (8\% starch, DM basis) blended with 5\% chopped hay fed free choice; (2) high starch textured starter (45\% starch, DM basis) blended with $5 \%$ chopped hay fed free choice; (3) low starch pelleted starter ( $8 \%$ starch, DM basis) fed at a rate up to $2 \mathrm{~kg}$ of $\mathrm{DM} / \mathrm{d}(2.3 \mathrm{~kg}$ as-fed), with free-choice long grass hay; or (4) high starch textured starter ( $45 \%$ starch, DM basis) fed at a rate of up to $2 \mathrm{~kg}$ of $\mathrm{DM} / \mathrm{d}(2.3 \mathrm{~kg}$ as-fed), with free-choice long grass hay. Free-choice hay was placed at the opposite end of the $2.4 \mathrm{~m}$ long feed bunk with animal dividers (approximately $0.6 \mathrm{~m}$ for hay and $1.8 \mathrm{~m}$ for starter). Ingredient composition of starters are shown in Table 1. Analyzed nutrient composition of all feeds are shown in Table 2. Water was offered free choice.

In trial 2,48 calves, $(76.4 \pm 1.55 \mathrm{~kg}$ of initial BW; 6 pens of 4 calves/pen) were randomly assigned to 1 of 2 diets: (1) ad libitum access to a blend of $95 \%$ high starch textured starter (42\% starch) and 5\% chopped grass hay (TEXLH); or (2) high starch textured starter fed up to $2.35 \mathrm{~kg}$ of DM/d $(2.7 \mathrm{~kg}$ as fed $)$ with free-choice long grass hay (TEXUH). Free-choice hay was placed at the opposite end of the $2.4 \mathrm{~m}$ long feed bunk with animal dividers (approximately $0.6 \mathrm{~m}$ for hay and $1.8 \mathrm{~m}$ for starter). Starter in trial 2 was of similar ingredient composition to high starch starter in trial 1. Analyzed nutrient composition of all feeds are shown in Table 2. Water was offered free choice.

Before trial 1, calves were fed $0.66 \mathrm{~kg}$ of DM from a $25 \% \mathrm{CP}, 17 \%$ fat milk replacer (MR) before weaning at 6 wk of age. Calves were fed (ad libitum) a $41 \%$ starch, $20 \%$ CP textured starter made with whole corn, whole oats, a protein supplement pellet, and molasses until trial 1 began. Before trial 2, calves were fed $0.66 \mathrm{~kg}$ of DM from a $25 \%$ CP, $20 \%$ fat MR from d 1 to 7 , fed 0.88 
Table 1. Ingredient composition of starters fed in trials 1 and 2

\begin{tabular}{|c|c|c|c|}
\hline \multirow[b]{2}{*}{ Ingredient ( $\%$ as fed) } & \multicolumn{2}{|c|}{ Trial 1} & \multirow{2}{*}{$\begin{array}{c}\text { Trial } 2 \\
\text { Textured }\end{array}$} \\
\hline & Textured & Pelleted & \\
\hline \multicolumn{4}{|l|}{ Outside pellet } \\
\hline Corn, whole & 44.50 & - & 37.00 \\
\hline Oats, whole & 25.00 & - & 25.00 \\
\hline Molasses & 3.00 & - & 3.00 \\
\hline \multicolumn{4}{|l|}{ Within pellet } \\
\hline Soybean meal & 18.78 & 13.90 & 25.88 \\
\hline Wheat middlings & 4.19 & 20.00 & 3.76 \\
\hline Calcium carbonate & 1.07 & 0.08 & 1.20 \\
\hline Vitamins, trace minerals & 0.69 & 0.75 & 0.75 \\
\hline Salt & 0.62 & 0.60 & 0.79 \\
\hline Monocalcium phosphate & 0.62 & 0.67 & 0.77 \\
\hline Maltodextrin & 0.55 & 2.50 & 0.70 \\
\hline Alfalfa meal & 0.55 & - & 0.70 \\
\hline Fat & 0.21 & 2.00 & 0.26 \\
\hline Magnesium oxide & 0.18 & - & - \\
\hline Deccox $6 \%^{1}$ & 0.04 & - & - \\
\hline Soybean hulls & - & 56.00 & - \\
\hline Deccox $0.5 \%^{2}$ & - & 0.50 & - \\
\hline Ameribond $2 \mathrm{x}^{3}$ & - & 0.50 & - \\
\hline Molasses & - & 2.50 & - \\
\hline Clarifly larvicide $0.67 \%^{4}$ & - & - & 0.09 \\
\hline Flavor & - & - & 0.04 \\
\hline Bovatec $91^{5}$ & - & - & 0.03 \\
\hline Calcium propionate & - & - & 0.02 \\
\hline
\end{tabular}

${ }^{1}$ Decoquinate 6\%. Zoetis, Parsippany, NJ.

${ }^{2}$ Decoquinate 0.5\%. Diluted Deccox 6\%, Provimi, Brookville, $\mathrm{OH}$.

${ }^{3}$ Pellet binder. LignoTech USA Inc., Bridgewater, NJ.

${ }^{4}$ Diflubenzuron $0.67 \%$, Wellmark International, Schaumburg, IL.

${ }^{5}$ Lasalocid 90.7 g per pound. Zoetis, Parsippany, NJ.

$\mathrm{kg}$ of DM from d 8 to 42 , and $0.33 \mathrm{~kg}$ of DM from d 43 to 49. Calves in trial 2 were fed a starter similar to that fed to calves before trial 1. Before the trial, all calves were housed in individual pens bedded with long wheat straw in a curtain-sided, naturally ventilated nursery.

Calves were weighed, scored for body condition (1 being thin and 5 being obese modified from Wildman et al., 1982), and hip widths were measured initially and at 28 and $56 \mathrm{~d}$. Feed was offered daily for minimal refusals (composited by pen by week and sampled for analysis). Nutrient analysis of the refused feed for each pen and week resembled the feed offered. Trial 1 was conducted from October 9 to December 4 with an average temperature of $7^{\circ} \mathrm{C}$ (ranged from -9 to $27^{\circ} \mathrm{C}$ ) and an average humidity of $73 \%$ (ranged from 37 to 100\%). Trial 2 was conducted from November 14 to January 8 with an average temperature of $1^{\circ} \mathrm{C}$ (ranged -10 to $15^{\circ} \mathrm{C}$ ) and an average relative humidity of $90 \%$ (54 to $100 \%)$.

Composites of feeds and refused feed were analyzed (AOAC International, 2000) for DM (oven method 930.15), ash (oven method 942.05), Ca and P (dry ashing, acid digestion, analysis by inductively coupled plasma; method 985.01), CP (Kjeldahl method 988.05), fat (alkaline treatment with Roese-Gottlieb method 932.06 for MR; diethyl ether extraction method 2003.05 for starters and hay), NDF with ash by the procedure of Van Soest et al. (1991) without sodium sulfite or $\alpha$-amylase, ADF with ash (Robertson and Van Soest, 1981), starch ( $\alpha$-amylase method; Hall, 2009), and sugar (colorimetric method; DuBois et al., 1956).

For each trial, daily intakes were reduced to means in 28 -d periods for each pen of calves. Data were analyzed as a completely randomized design (with a $2 \times 2$ factorial arrangement of treatments in trial 1, specifically), or when applicable a completely randomized design with repeated measures in 28-d periods using MIXED procedures (SAS, 2012, version 9.4, SAS Institute Inc., Cary, NC). Pen (4 calves/ pen) was the experimental unit. In the mixed models with repeated measurements, pen was treated as a random variable and the first order autoregressive structure was selected as the appropriate covariance structure based on Akaike information

Table 2. Analyzed nutrient content of feeds in trial 1 and 2

\begin{tabular}{|c|c|c|c|c|c|}
\hline \multirow[b]{2}{*}{ Item } & \multicolumn{3}{|c|}{ Trial 1} & \multicolumn{2}{|c|}{ Trial 2} \\
\hline & Textured & Pelleted & Hay & Textured & Hay \\
\hline \multicolumn{6}{|l|}{ Nutrient (\% of DM) } \\
\hline DM (\% as-fed) & 87.8 & 87.7 & 87.7 & 85.8 & 84.4 \\
\hline $\mathrm{CP}$ & 18.4 & 18.5 & 14.7 & 20.1 & 10.1 \\
\hline Fat & 3.9 & 4.4 & 3.3 & 3.9 & 2.4 \\
\hline $\mathrm{ADF}$ & 9.5 & 34.4 & 37.6 & 5.9 & 37.7 \\
\hline NDF & 19.1 & 51.2 & 62.7 & 13.8 & 57.4 \\
\hline Ash & 6.6 & 7.1 & 8.9 & 7.1 & 9.7 \\
\hline Starch & 45.2 & 8.2 & 1.4 & 41.8 & 6.9 \\
\hline Sugar & 6.2 & 5.9 & 9.8 & 6.2 & 3.5 \\
\hline \multicolumn{6}{|l|}{ Calculated } \\
\hline $\mathrm{DE}(\mathrm{Mcal} / \mathrm{kg})$ & 3.6 & 3.3 & 2.6 & 3.7 & 2.5 \\
\hline ME (Mcal/kg) & 3.1 & 2.9 & 2.2 & 3.1 & 2.2 \\
\hline Geometric mean particle size $(\mu \mathrm{m})$ & 3,306 & 875 & $2,442^{1}$ & 3,237 & $2,102^{1}$ \\
\hline
\end{tabular}

${ }^{1}$ For chopped hay. Particle size was not measured for long hay. 
Table 3. Performance of calves in trial 1 fed diets with different amounts of grass hay and starch

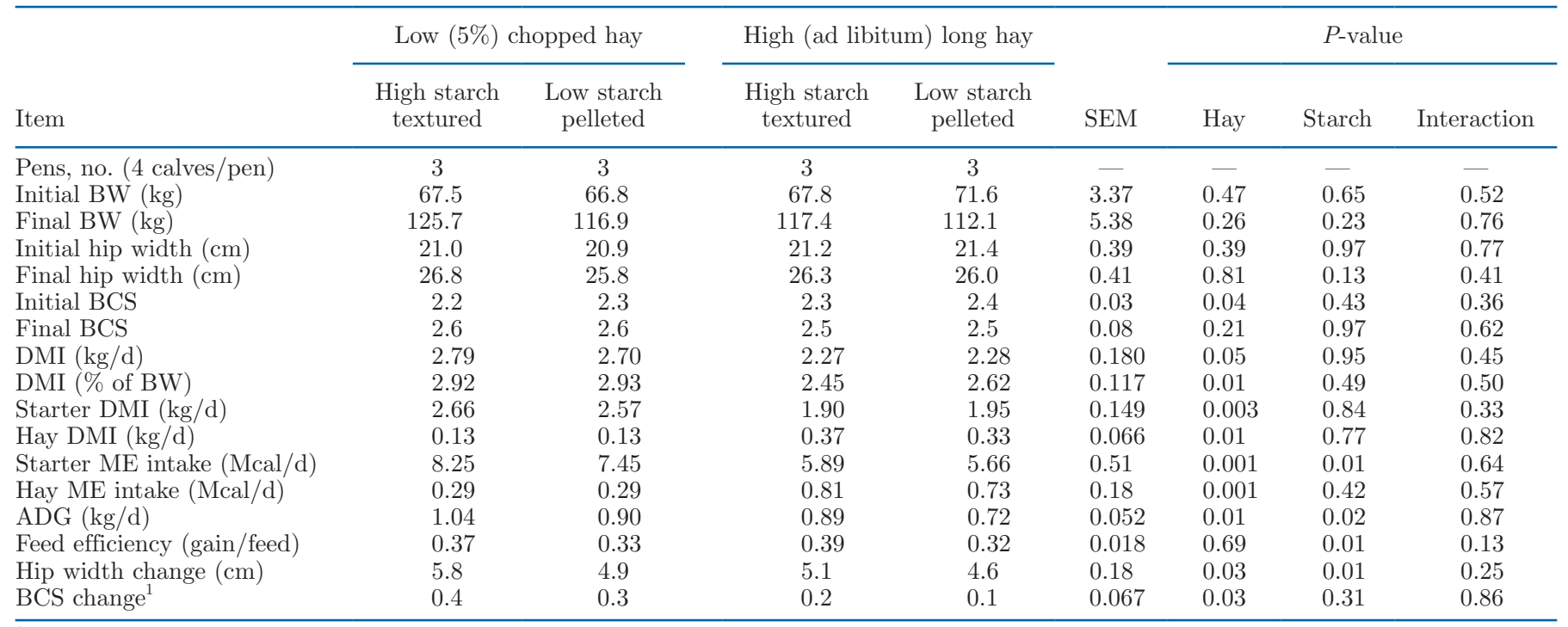

${ }^{1} 1$ to 5 point system $(1=$ thin, $5=$ obese $)$.

criterion. Initial or final BCS, or BCS change during 56 d were analyzed using Kruskal-Wallis test with PROC NPARIWAY. Furthermore, daily intakes were reduced to weekly means, and the potential relationship between ad libitum hay intake with age (wk 1 to 8 ) was examined in 2 trials (St-Pierre, 2001). Calves in trial 1 were ad libitum fed free-choice long hay, with starters containing low (dietary treatment 3 ) versus high (dietary treatment 4) amounts of starch; thus, each of 2 treatments was considered specifically as a trial (i.e., trial 1-A and trial 1-B) being included in the statistical model for the analysis, which would be the most appropriate way to detect true hay intake response as calves aged from wk 1 to 8 . Significance was defined as $P \leq 0.05$, whereas $0.05<P \leq 0.10$ was considered to indicate a trend toward a significant effect.

\section{RESULTS}

In trial 1 , no differences $(P>0.05)$ were observed among treatments for initial BW or hip width (Table $3)$. Initial BCS in trial 1 differed $(P=0.04)$. No interactions of main effects were observed. Feed efficiency (0.38 vs. 0.325$)$, ADG (0.965 vs. $0.81 \mathrm{~kg} / \mathrm{d}$ ), and hip width change $(5.45$ vs. $4.75 \mathrm{~cm})$ were greater $(P<0.05)$ for calves fed the high versus low starch diets, regardless of hay supplementation level. Overall DMI (2.75 vs. $2.28 \mathrm{~kg} / \mathrm{d}$ ), starter intake (2.62 vs. $1.93 \mathrm{~kg} / \mathrm{d})$, starter ME intake (7.85 vs. $5.78 \mathrm{Mcal} / \mathrm{d})$, ADG (0.97 vs. 0.81 $\mathrm{kg} / \mathrm{d})$, and change in hip width (5.35 vs. $4.85 \mathrm{~cm})$ were greater $(P<0.05)$ for calves fed $5 \%$ chopped hay compared with those fed ad libitum long hay, regardless of starch level (Table 3). For calves fed ad libitum hay, intake of hay increased from approximately $0.3 \%$ of DMI in wk 1 to approximately $31 \%$ of DMI by wk 8 (Figure 1; Table 4). Simple regression of total DMI by week is shown in Figure 1. Estimates of total DMI should be more accurate than estimates of starter and hay intake because of difficulty and errors in separating refused feed.

In trial 2 , no differences $(P>0.05)$ were observed between treatments for initial BW, hip width, hip height, or BCS (Table 5). Feed efficiency, DM and ME intakes, and all growth measurements were greater $(P$ $<0.05$ ) for calves fed TEXLH compared with those fed TEXUH. For calves fed TEXUH, intake of hay increased from approximately $0.3 \%$ of DMI in wk 1 to

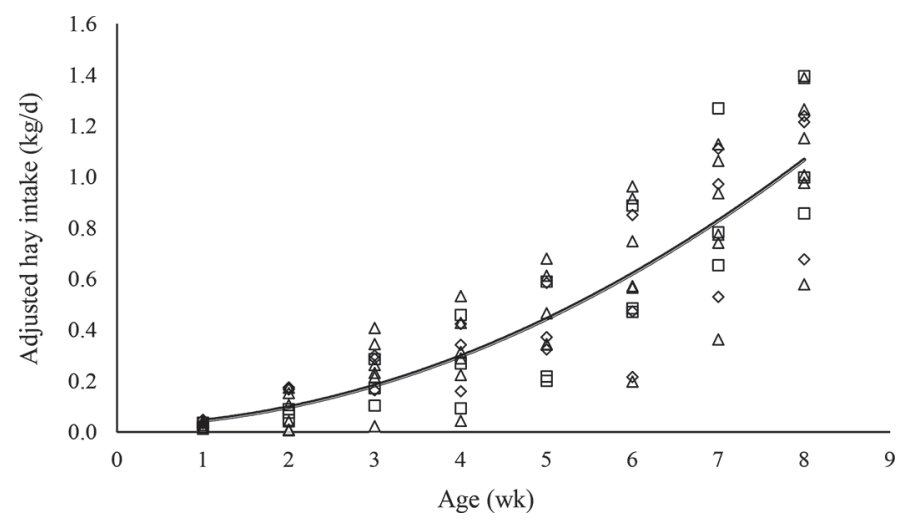

Figure 1. Relationship between adjusted ad libitum hay intake $(\mathrm{DM} ; \mathrm{kg} / \mathrm{d})$ and age (week) for all pens of calves in 2 trials. The adjusted hay intake $(\mathrm{DM} ; \mathrm{kg} / \mathrm{d})=0.01548 \times$ age $(\text { week })^{2}+0.006832 \times$ age (week) +0.02266 ; across trials, quadratic $P<0.001 ; \mathrm{R}^{2}=0.77 ; \mathrm{n}$ $=12$. Legend: trial 1-A $(\diamond)$, trial 1-B $(\square)$, and trial $2(\Delta)$. 


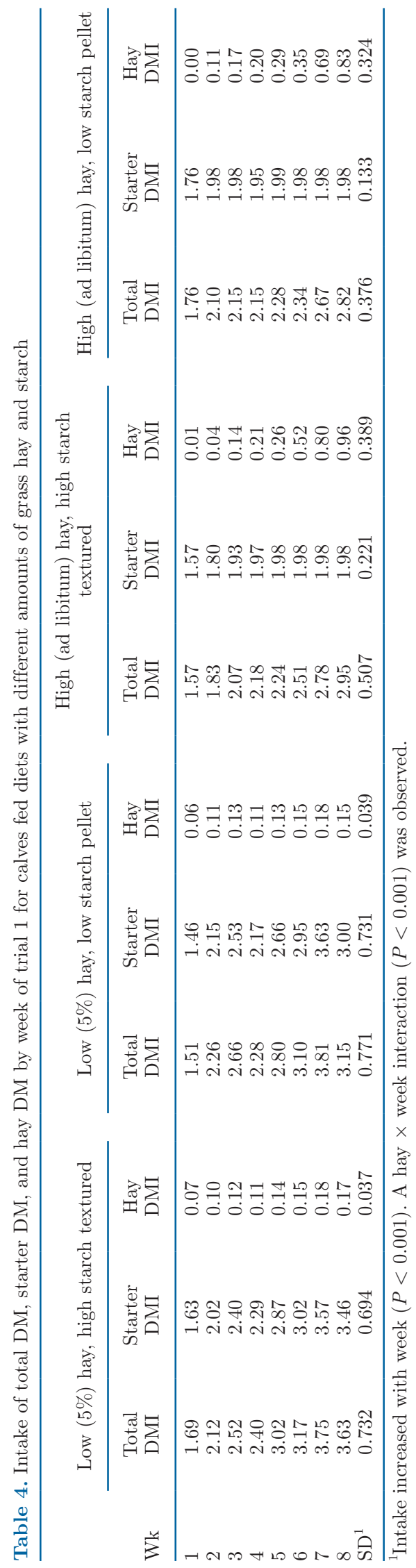

approximately $37 \%$ of total DMI by wk 8 (Table 6 ). As in trial 1, estimates of total DMI should be more accurate than estimates of starter and hay intake because of difficulty and errors in separating refused feed.

When calves were fed long hay, waste of hay was evident by the amount of forage observed on the ground by the feeders. This forage was counted as intake in tables and figures because it was trampled by the calves and could not be captured as orts. Therefore, intake would be inflated, leading to some error in estimates. Waste of feed was not evident when chopped hay was blended at $5 \%$ with the starter. Waste is an issue with older cattle on farms (Buskirk et al., 2003) and beyond the scope of this research. Adequate feed bunk space and feed bunk dividers should have reduced the chances of dominant calves consuming more than their fair share of starter.

\section{DISCUSSION}

It is common practice on farms to feed young, recently weaned calves limited starter with free-choice hay. However, due to the small capacity of the rumen, as well as the limited ability to digest fibrous feeds, this method can lead to decreased DMI in many cases, resulting in decreased growth. To support optimal BW gain and frame growth, young calves should be fed easily digestible feeds. Calf starters with greater amounts of starch are easily digested by young calves (Hill et al., 2016). Fermentation of starch leads to production of propionate and butyrate, which are important VFA for rumen development (Carroll and Hungate, 1954; Brownlee, 1956; Sander et al., 1959), whereas fermentation of forage leads to production of acetate (Davis and Drackley, 1998). As calves age and intake of starter increases significantly, rapid fermentation of starch can lead to rumen acidosis, indicating a need for some forage to stimulate rumination and production of saliva to buffer rumen $\mathrm{pH}$ (Khan et al., 2011). Therefore, both concentrate and forage are required in the diet of young calves for optimal rumen growth and health by stimulating the rumen microbial population (Brownlee, 1956); however, the optimal amount and age to supply forage is not well defined and appears to be affected by many factors, including milk allowance (Khan et al., 2011) and starter form (Imani et al., 2017).

In trial 1, increased ADG and greater hip width gain were observed in calves fed high starch textured versus low starch pelleted diets, which is consistent with other research with 2- to 4-mo-old calves from our laboratory (Hill et al., 2016). In the research of Hill et al. (2016), in trial 1, OM digestibility of a high starch (52\% starch) textured starter blended with $5 \%$ chopped grass hay and fed ad libitum was $7 \%$ greater than OM digestibility of low starch (20\% starch) pelleted starter blended with 
Table 5. Performance of calves in trial 2 fed $5 \%$ grass hay with $95 \%$ concentrate in TMR or ad libitum grass hay with up to $2.7 \mathrm{~kg}$ of concentrate (as fed; $2.35 \mathrm{~kg}$ of DM) from 2 to 4 mo of age ( $56 \mathrm{~d}$ )

\begin{tabular}{lcccc}
\hline Item & $5 \%$ hay & Ad libitum hay & SEM & $P$-value \\
\hline Initial BW (kg) & 76.9 & 75.9 & 1.55 & 0.687 \\
Final BW (kg) & 145.1 & 132.5 & 2.84 & 0.010 \\
Initial hip width (cm) & 21.4 & 21.1 & 0.24 & 0.489 \\
Final hip width (cm) & 26.2 & 25.0 & 0.22 & 0.004 \\
Initial height (cm) & 81.0 & 80.9 & 0.57 & 0.855 \\
Final hip height (cm) & 94.9 & 91.8 & 0.71 & 0.011 \\
Initial BCS & 2.2 & 2.2 & 0.02 & 0.525 \\
Final BCS & 2.8 & 2.4 & 0.04 & 0.001 \\
DMI (kg/d) & 3.42 & 2.95 & 0.084 & 0.003 \\
Starter DMI (kg/d) & 3.26 & 2.31 & 0.082 & 0.009 \\
Hay DMI (kg/d) & 0.16 & 0.64 & 0.054 & 0.013 \\
Starter ME intake (Mcal/d) & 10.11 & 7.16 & 0.262 & 0.001 \\
Hay ME intake (Mcal/d) & 0.35 & 1.41 & 0.121 & 0.006 \\
DMI (\% of BW) & 3.08 & 2.84 & 0.031 & 0.0002 \\
ADG (kg/d) & 1.22 & 1.01 & 0.031 & 0.001 \\
Feed efficiency (gain/feed) & 0.367 & 0.348 & 0.0061 & 0.050 \\
Hip width change (cm) & 4.8 & 3.9 & 0.11 & 0.0001 \\
BCS change & 0.6 & 0.3 & 0.05 & 0.001 \\
\hline
\end{tabular}

${ }^{1} 1$ to 5 point system $(1=$ thin, $5=$ obese $)$.

$5 \%$ chopped grass hay and fed ad libitum. In trial 2, when evaluating pelleted starters with different starch concentrations blended with $5 \%$ chopped grass hay, high starch ( $42 \%$ starch) diets based on corn had $8 \%$ greater OM digestibility than low starch diets based on either wheat middlings ( $27 \%$ starch) or soybean hulls (13\% starch). Overall, in both trials starch digestibility was $>95 \%$, whereas NDF digestibility was $<71 \%$, which explains the greater OM digestion observed in high versus low starch starters blended with $5 \%$ chopped hay. Although digestibility was not measured in the 2 current trials, the greater digestibility typically seen with high starch diets fed with only $5 \%$ hay would explain the increased performance.

Retention time of particles in the rumen also affects performance. Mean retention of particles in the rumen increases from $22 \mathrm{~h}$ at $7 \mathrm{wk}$ of age to $44 \mathrm{~h}$ at $13 \mathrm{wk}$ of age in calves fed diets consisting of $15 \%$ chopped grass hay and $85 \%$ concentrate, when weaned at $5 \mathrm{wk}$ of age (Vazquez-Anon et al., 1993). This implies that greater rumen digestion occurs as the calf ages, and suggests that fibrous feeds such as soybean hulls, wheat middlings, and distillers grains may be better suited for older rather than younger calves. Younger calves should be fed diets with digestible ingredients that support rumen development and provide adequate particle size to prevent hyper-keratinization of papillae to achieve optimal performance (NRC, 2001).

Performance is also affected by diet composition, due to the effect on gut fill, specifically when forage is fed to young calves. When measurements of ADG are made in calves less than $4 \mathrm{mo}$ of age, gut fill can be a significant source of error, specifically in studies that investigate effects from starters with different starch levels that differ in digestibility fed with different types and amounts of forage sources (Jahn and Chandler, 1976; Khan et al., 2011). Other researchers suggest that gut fill should not be considered a factor when forage intake is $<10 \%$

Table 6. Intake of total DM, starter DM, and hay DM by week of trial 2 for calves fed $5 \%$ grass hay with $95 \%$ concentrate in TMR or ad libitum grass hay with up to $2.7 \mathrm{~kg}$ of concentrate (as fed; $2.35 \mathrm{~kg}$ of DM) from 2 to 4 mo of age (56 d)

\begin{tabular}{|c|c|c|c|c|c|c|}
\hline Wk & \multicolumn{3}{|c|}{ Low $(5 \%)$ hay, high starch textured } & \multicolumn{3}{|c|}{ High (ad libitum) hay, high starch textured } \\
\hline 1 & 2.17 & 2.06 & 0.11 & 2.24 & 2.17 & 0.07 \\
\hline 3 & 2.99 & 2.85 & 0.14 & 2.71 & 2.33 & 0.38 \\
\hline 4 & 3.18 & 3.02 & 0.15 & 2.82 & 2.34 & 0.48 \\
\hline 5 & 3.55 & 3.38 & 0.17 & 2.96 & 2.35 & 0.61 \\
\hline $\mathrm{SD}^{1}$ & 0.815 & 0.779 & 0.035 & 0.512 & 0.080 & 0.642 \\
\hline
\end{tabular}

${ }^{1}$ Intake increased with week $(P<0.001)$. A hay $\times$ week interaction $(P<0.001)$ was observed. 
of total DMI (Imani et al., 2017). However, in the metaanalysis of Imani et al. (2017), level of milk fed was not considered, which has been shown to affect results of forage provision as well (Khan et al., 2011; Mirzaei et al., 2017). In our data, we did not correct for gut fill using the equation of Jahn and Chandler (1976) as some do to express an estimate of empty BW gain. However, in trial 1, both hip width change and ADG were greater when calves were limited to $5 \%$ chopped hay with $95 \%$ starter fed ad libitum compared with calves limited to $2.3 \mathrm{~kg}$ starter with ad libitum hay. In trial 2, hip width change and ADG were greater when calves were fed TEXLH compared with calves fed TEXUH. The results from our research indicate that the lower starch, higher fiber starter, as well as greater fiber from hay, reduced performance.

Our group previously evaluated performance when feeding a textured starter, based on whole grains, a pelleted starter, or a meal starter all blended with $5 \%$ chopped grass hay to calves from 2 to 4 mo of age (Hill et al., 2012). The textured and pelleted feeds supported similar ADG and hip width gain, whereas a meal feed had lesser ADG and DMI. Starter intake was greater, but ADG was similar, in calves fed a textured starter compared with those fed a pelleted starter in Bach et al. (2007), but they only reported mostly preweaning ADG to approximately $70 \mathrm{~d}$ of age. A study conducted by Coverdale et al. (2004) found that calves fed forage with coarse starter had greater ADG than calves fed ground starter postweaning to 2 mo of age. In another study, calves fed a textured starter based on steamflaked corn and barley had less DMI but similar ADG as calves fed a ground starter with alfalfa hay (Moeini et al., 2017). In trial 1, calves fed a high starch textured starter based on whole corn and oats had greater DMI, ADG, and hip width gain compared with calves fed a low starch pelleted starter. Increased DMI with textured feeds may be related to the effect that grain processing has on rumen $\mathrm{pH}$. Rumen $\mathrm{pH}$ was also reduced when calves $<10$ wk of age were fed starters with barley or wheat, compared with corn or oats (Khan et al., 2007). Starters with whole corn supported similar rumen $\mathrm{pH}$ to pelleted diets fed with chopped straw. Calves fed a textured starter based on steam-flaked corn and barley had greater ADG pre- and postweaning, and greater rumen $\mathrm{pH}$, than those fed a mash starter (Omidi-Mirzaei et al., 2018). Calves fed textured feeds had greater DMI than pelleted and meal feeds, indicating it is advantageous to feed textured starters based on whole grains (Hill et al., 2012). Calves under 9 wk of age fed starter based on whole corn had greater rumen $\mathrm{pH}$ than calves fed pelleted or meal starters (Terré et al., 2015), which likely plays a role on DMI and growth.
Intake and ADG in calves 8 to 16 wk of age were optimized when $1.5 \%$ added NDF from chopped grass hay, chopped alfalfa hay, or chopped wheat straw was added to the diet (Hill et al., 2010). This amount equates to the $5 \%$ chopped grass hay treatment in trial 1 and 2 , and was similar to amounts consumed ad libitum by several treatments reported by Castells et al. (2012) in calves $<2$ to 10 wk of age. In Coverdale et al. (2004), ADG was greater for calves fed coarse or ground starter, with 7.5 or $15 \%$ bromegrass hay, compared with calves fed coarse starter with no hay. However, in this study by Coverdale et al. (2004), calves were also fed the same diets in the preweaning period and were only tracked for 2 wk postweaning. Calves that were fed a ground starter with alfalfa hay had greater DMI and preweaning ADG than calves fed pelleted or ground starters without forage but were similar to those fed textured starter (Pazoki et al., 2017), indicating that textured calf starters can support a healthy rumen, similar to inclusion of forage to ground starters.

Kertz (2007) pointed out that calves on pelleted starters may be acidotic and may consume bedding as a relief mechanism for rumen acidosis. In our trials, as Kertz (2007) suggested, we do not know if calves consumed straw bedding. However, we did offer coarsely chopped and long hay as treatments and intake of hay did not differ due to level of starch in the starter. In trial 1 , we confounded form of starter with level of starch. As mentioned above, in prior studies in our facilities, starter form (textured vs. pelleted) did not alter intake or growth in calves when offered high starch starters (Hill et al., 2012). However, growth was greater with high versus low starch starters (Hill et al., 2016) that were of similar form. However, straw bedding was used and could have been consumed.

Size of forage particles appear to be important as Montoro et al. (2013) reported that 10\% coarsely processed grass hay improved DMI and digestion of DM, $\mathrm{CP}, \mathrm{NDF}$, and ADF compared with finely processed grass hay, suggesting positive effects on the rumen environment. However, Suarez-Mena et al. (2016) did not find that particle size of straw affected the rumen environment or rumen development. Hill et al. (2010) reported no differences in calf intake or growth when long or chopped alfalfa hay was fed to calves from 2 to 4 mo of age. When 0 - to 8 -wk-old calves were fed cottonseed hulls or chopped grass hay blended into pelleted, high starch starters at $0,2.5$, and $5 \%$, forage or roughage reduced growth (Hill et al., 2008), contrary to the results of Castells et al. (2012). The conflicting results may be due to the age difference in calves, as Castells et al. (2012) fed calves up to 10 vs. 8 wk of age in Hill et al. (2008). Calves consume very little forage 
free choice at young ages, and intake increases from 1 to 10 wk old (Khan et al., 2011), which could also affect results.

Intake of ad libitum hay in the current trials was highly variable (Figure 1), which is in agreement with Hill et al. $(2019 \mathrm{a}, \mathrm{b})$ in calves 0 to 8 wk of age. Those researchers observed highly variable forage intake, no correlation between forage intake and starter intake, and found that some calves from 6 to 8 wk of age do not consume much forage at all, which created variability in intakes and growth in calves. Their research also suggested that very little straw bedding was consumed by the calves. A similar effect was observed in Castells et al. (2012), where calves were allowed ad libitum intake of oat hay, barley straw, or ryegrass and consumed a final forage:concentrate ratios of 8:92, 5:95, and 4:96 when fed with calf starter. Forage intake varied by $2.5-$ fold and 2-fold among pens of calves during the last wk of trials 1 and 2, respectively. In the first few weeks of the trial, when starter was restricted and fed with freechoice hay, intake of hay was low (Table 5). Total DMI was less for calves fed limited starter with ad libitum hay compared with calves fed only $5 \%$ chopped hay blended with $95 \%$ starter fed ad libitum. Increase in total DMI with time was $0.16 \mathrm{~kg}$ of $\mathrm{DM} /$ wk for calves fed ad libitum grass hay and $0.26 \mathrm{~kg}$ of $\mathrm{DM} /$ wk for calves fed $5 \%$ chopped hay blended with $95 \%$ starter fed ad libitum. These differences in intake indicate that rumen fill was likely restricting intake of the ad libitum hay treatment group. The restricted intake, combined with a presumed lower digestibility of hay versus starter could be the cause of the lesser growth rates of calves fed ad libitum hay (Hill et al., 2019a).

\section{CONCLUSIONS}

Ad libitum hay intake was highly variable among pens and differed approximately 2 -fold by the last week of the trials. In trial 1, high starch (51\%), low fiber textured starters supported 19\% more ADG and $14 \%$ more hip width change than low starch (11\%), high fiber pelleted starters, independent of forage feeding program. In both trials, restricted feeding of starter with ad libitum long grass hay reduced total DMI 13 to $17 \%$, ADG by $20 \%$, and hip width change by 10 to $23 \%$ compared with $95 \%$ starter blended with 5\% chopped hay and fed ad libitum. This study supports that forage should be fed at a restricted rate to calves from 2 to 4 mo of age to achieve optimal growth.

\section{ACKNOWLEDGMENTS}

The authors thank the staff of the Nurture Research Center for their care of the calves and execution of the research protocol. This research was fully funded by Provimi, a division of Cargill Animal Nutrition. The authors have not stated any conflicts of interest.

\section{REFERENCES}

AOAC International. 2000. Official Methods of Analysis. Vol. I. 17th ed. AOAC Int., Arlington, VA.

Bach, A., A. Gimenez, J. L. Juaristi, and J. Ahedo. 2007. Effects of physical form of a starter for dairy replacement calves on feed intake and performance. J. Dairy Sci. 90:3028-3033. https://doi .org/10.3168/jds.2006-761.

Bateman, H. G., II, T. M. Hill, J. M. Aldrich, and R. L. Schlotterbeck. 2009. Effects of corn processing, particle size, and diet form on performance of calves in bedded pens. J. Dairy Sci. 92:782-789. https://doi.org/10.3168/jds.2008-1242.

Brownlee, A. 1956. The development of rumen papillae in cattle fed on different diets. Br. Vet. J. 112:369-375. https://doi.org/10.1016/ S0007-1935(17)46456-6.

Buskirk, D. D., A. J. Zanella, T. M. Harrigan, J. L. Van Lente, L. M. Gnagey, and M. J. Kaercher. 2003. Large round bale feeder design affects hay utilization and beef cow behavior. J. Anim. Sci. 81:109-115. https://doi.org/10.2527/2003.811109x.

Carroll, E. J., and R. E. Hungate. 1954. The magnitude of the microbial fermentation in the bovine rumen. Appl. Microbiol. 2:205-214.

Castells, L., A. Bach, G. Araujo, C. Montoro, and M. Terré. 2012. Effect of different forage sources on performance and feeding behavior of Holstein calves. J. Dairy Sci. 95:286-293. https://doi.org/10 $.3168 /$ jds.2011-4405.

Castells, L., A. Bach, A. Aris, and M. Terré. 2013. Effects of forage provision to young calves on rumen fermentation and development of the gastrointestinal tract. J. Dairy Sci. 96:5226-5236.

Coverdale, J. A., H. D. Tyler, J. D. Quigley III, and J. A. Brumm. 2004. Effect of various levels of forage and form of diet on rumen development and growth in calves. J. Dairy Sci. 87:2554-2562. https://doi.org/10.3168/jds.S0022-0302(04)73380-9.

Davis, C. L., and J. K. Drackley. 1998. The Development, Nutrition, and Management of the Young Calf. Iowa State University Press, Ames.

DuBois, M., K. A. Gilles, J. K. Hamilton, P. A. Rebers, and F. Smith. 1956. Colorimetric method for determination of sugars and related substances. Anal. Chem. 28:350-356. https://doi.org/10.1021/ ac60111a017.

FASS. 2010. Guide for the care and use of agricultural animals in research and teaching. (3rd ed.). Federation of Animal Science Societies, Champaign, IL.

Hall, M. B. 2009. Analysis of starch, including maltooligosaccharides, in animal feeds: A comparison of methods and a method recommended for AOAC collaborative study. J. AOAC Int. 92:42-49.

Hill, T. M., H. G. Bateman II, J. M. Aldrich, and R. L. Schlotterbeck. 2008. Effects of the amount of chopped hay or cottonseed hulls in a textured calf starter on young calf performance. J. Dairy Sci. 91:2684-2693. https://doi.org/10.3168/jds.2007-0935.

Hill, T. M., H. G. Bateman II, J. M. Aldrich, and R. L. Schlotterbeck. 2010. Roughage amount, source, and processing for diets fed to weaned dairy calves. Prof. Anim. Sci. 26:181-187. https://doi.org/ 10.15232/S1080-7446(15)30578-7.

Hill, T. M., H. G. Bateman II, J. M. Aldrich, and R. L. Schlotterbeck. 2012. High-starch, coarse-grain, low-fiber diets maximize growth of weaned dairy calves less than 4 months of age. Prof. Anim. Sci. 28:325-331. https://doi.org/10.15232/S1080-7446(15)30363-6.

Hill, T. M., T. S. Dennis, F. X. Suarez-Mena, J. D. Quigley, K. M. Aragona, and R. L. Schlotterbeck. 2019a. Effects of free-choice hay and straw bedding on digestion of nutrients in 7-week old Holstein calves. Appl. Anim. Sci. 35:312-317. https://doi.org/10.15232/aas .2019-01855.

Hill, T. M., J. D. Quigley, H. G. Bateman II, J. M. Aldrich, and R. L. Schlotterbeck. 2016. Source of carbohydrate and metabolizable lysine and methionine in the diet of recently weaned dairy calves 
on digestion and growth. J. Dairy Sci. 99:2788-2796. https://doi .org/10.3168/jds.2015-10571.

Hill, T. M., F. X. Suarez-Mena, T. S. Dennis, J. D. Quigley, and R. L. Schlotterbeck. 2019b. Effects of free-choice hay on intake and growth of Holstein calves fed a textured starter to 2 months of age. Appl. Anim. Sci. 35:161-168. https://doi.org/10.15232/aas 2018-01826.

Imani, M., M. Mirzaei, B. Baghbanzadeh-Nobari, and M. H. Ghaffari. 2017. Effects of forage provision to dairy calves on growth performance and rumen fermentation: A meta-analysis and metaregression. J. Dairy Sci. https://doi.org/10.3168/jds.2016-11561.

Jahn, E., and P. T. Chandler. 1976. Performance and nutrient requirements of calves fed varying percentages of protein and fiber. J. Anim. Sci. 42:724-735. https://doi.org/10.2527/jas1976.423724x.

Kertz, A. F. 2007. Letter to the Editor: Pelleted calf starter with straw access can confound results: A comment on Bach et al. (2007). J. Dairy Sci. 90:4924.

Khan, M. A., H. J. Lee, W. S. Lee, H. S. Kim, S. B. Kim, K. S. Ki, S. J. Park, J. K. Ha, and Y. J. Choi. 2007. Starch source evaluation in calf starter: I. Feed consumption, body weight gain, structural growth, and blood metabolites in Holstein calves. J. Dairy Sci. 90:5259-5268

Khan, M. A., H. J. Lee, W. S. Lee, H. S. Kim, S. B. Kim, S. B. Park, K. S. Baek, J. K. Ha, and Y. J. Choi. 2008. Starch source evaluation in calf starter: II. Ruminal parameters, rumen development, nutrient digestibilities, and nitrogen utilization in Holstein calves. J. Dairy Sci. 91:1140-1149. https://doi.org/10.3168/jds.2007-0337.

Khan, M. A., D. M. Weary, and M. A. G. von Keyserlingk. 2011. Hay intake improves performance and rumen development of calves fed higher quantities of milk. J. Dairy Sci. 94:3547-3553. https://doi .org/10.3168/jds.2010-3871.

Mirghaffari, S. S., K. Karkoodi, A. Mirza-aghazadeh, and N. Maherisis. 2013. Effect of wheat processing on rumen characteristics and rumen parameters in Holstein-Friesian calves. J. Anim. Physiol. Anim. Nutr. (Berl.) 97:911-918. https://doi.org/10.1111/j.1439 -0396.2012.01337.x.

Mirzaei, M., M. Khorvash, G. R. Ghorbani, M. Kazemi-Bonchenari, and M. H. Ghaffari. 2017. Growth performance, feeding behavior and selected blood metabolites of Holstein dairy calves fed restricted amounts of milk: No interactions between sources of finely ground grain and forage provision. J. Dairy Sci. 100:1086-1094. https://doi.org/10.3168/jds.2016-11592.

Moeini, H., A. H. Mahdavi, A. Riasi, G. R. Ghorbani, E. Oskoueian, M. A. Khan, and M. H. Ghaffari. 2017. Effects of physical form of starter and forage provision to young calves on blood metabolites, liver composition and intestinal morphology. J. Anim. Physiol. Anim. Nutr. (Berl.). https://doi.org/10.1111/jpn.12485.

Montoro, C., E. K. Miller-Cushon, T. J. DeVries, and A. Bach. 2013. Effect of physical form of forage on performance, feeding behavior, and digestibility of Holstein calves. J. Dairy Sci. 96:1117-1124. https://doi.org/10.3168/jds.2012-5731.

National Research Council (NRC). 2001. Nutrient Requirements of Dairy Cattle. 7th rev. ed. Natl. Acad. Sci., Washington, DC.

Omidi-Mirzaei, H., A. Azarfar, A. Kiani, M. Mirzaei, and M. H. Ghaffari. 2018. Interaction between the physical forms of starter and forage source on growth performance and blood metabolites of Holstein dairy calves. J. Dairy Sci. 101:6074-6084. https://doi .org/10.3168/jds.2017-13892.

Pazoki, A., G. R. Ghorbani, S. Kargar, A. Sadeghi-Sefidmazgi, J. K. Drackley, and M. H. Ghaffari. 2017. Growth performance, nutrient digestibility, ruminal fermentation, and rumen development of calves during transition from liquid to solid feed: Effects of physical form of starter feed and forage provision. Anim. Feed Sci. Technol. 234:173-185. https://doi.org/10.1016/j.anifeedsci.2017 .06 .004 .

Porter, J. C., R. G. Warner, and A. F. Kertz. 2007. Effect of fiber level and physical form of starter on growth and development of dairy calves fed no forage. Prof. Anim. Sci. 23:395-400. https://doi.org/ 10.15232/S1080-7446(15)30994-3.

Robertson, J. B., and P. J. Van Soest. 1981. The Detergent System of Analysis and Its Application to Human Foods. Cornell University, Ithaca, NY.

Sander, E. G., R. G. Warner, H. N. Harrison, and J. K. Loosli. 1959. The stimulatory effect of sodium butyrate and sodium propionate on the development of rumen mucosa in the young calf. J. Dairy Sci. 42:1600-1605. https://doi.org/10.3168/jds.S0022 -0302(59)90772-6.

St-Pierre, N. R. 2001. Integrating quantitative findings from multiple studies using mixed model methodology. J. Dairy Sci. 84:741-755.

Suarez-Mena, F. X., A. J. Heinrichs, C. M. Jones, T. M. Hill, and J. D. Quigley. 2015. Digestive development in neonatal dairy calves with either whole or ground oats in the calf starter. J. Dairy Sci. 98:3417-3431. https://doi.org/10.3168/jds.2014-9193.

Suarez-Mena, F. X., A. J. Heinrichs, C. M. Jones, T. M. Hill, and J. D. Quigley. 2016. Straw particle size in calf starters: Effects on digestive system development and rumen fermentation. J. Dairy Sci. 99:341-353. https://doi.org/10.3168/jds.2015-9884.

Terré, M., Ll. Castells, M. A. Khan, and A. Bach. 2015. Interaction between the physical form of the starter feed and straw provision on growth performance of Holstein calves. J. Dairy Sci. 98:1101-1109. https://doi.org/10.3168/jds.2014-8151.

USDA. 2018. Health and Management Practices on U.S. Dairy Operations, 2014. USDA-APHIS-VS-CEAH-NAHMS. Fort Collins, CO. Accessed Apr. 22, 2019. https://www.aphis.usda.gov/animal _health/nahms/dairy/downloads/dairy14/Dairy14_dr_PartIII .pdf.

Van Soest, P. J., J. B. Robertson, and B. A. Lewis. 1991. Methods for dietary fiber, neutral detergent fiber, and nonstarch polysaccharides in relation to animal nutrition. J. Dairy Sci. 74:3583-3597. https://doi.org/10.3168/jds.S0022-0302(91)78551-2.

Vazquez-Anon, M., A. J. Heinrichs, J. M. Aldrich, and G. A. Varga. 1993. Effect of postweaning age on rate of in situ protein disappearance in calves weaned at 5 weeks of age. J. Dairy Sci. 76:2749 2757. https://doi.org/10.3168/jds.S0022-0302(93)77612-2.

Wildman, E. E., G. M. Jones, P. E. Wagner, R. L. Boman, H. F. Troutt Jr., and T. N. Lesch. 1982. A dairy cow body condition scoring system and its relationship to selected production characteristics. J. Dairy Sci. 65:495-501. https://doi.org/10.3168/jds .S0022-0302(82)82223-6.

\section{ORCIDS}

K. M. Aragona (1) https://orcid.org/0000-0003-3674-838X

F. X. Suarez-Mena ๑ https://orcid.org/0000-0002-1546-5893

T. S. Dennis (단 https://orcid.org/0000-0003-3424-5498

J. D. Quigley @ https://orcid.org/0000-0001-8400-8963

W. Hu ๑ https://orcid.org/0000-0002-1307-3458

T. M. Hill ๑ https://orcid.org/0000-0003-1304-5016

R. L. Schlotterbeck $\odot$ https://orcid.org/0000-0002-5305-3945 